\title{
Simple payback time of semi-flexible monocrystalline silicon solar panel used for solar vehicles
}

\author{
Turhan Koyuncu
}

University of Adiyaman, Faculty of Technology, Adiyaman, Turkey.

\begin{abstract}
In this experimental investigation, simple payback time (SPT) of semi-flexible monocrystalline silicon solar panel used for solar vehicles (SV); a solar car called "Firat Force" and a solar minibus called "Commagene" was determined when replaced with an equal gasoline internal combustion engine (ICE). In addition, SPT of these solar vehicles was also calculated when they operated as electric vehicles (EV) and replaced with an equal gasoline internal combustion engine. These two solar vehicles were used for people transportation about $1000 \mathrm{~km}$ in Adiyaman city, Turkey, during one year (June 2010-May 2011) for test. The results of the study showed us that SPT of solar vehicles, Firat Force and Commagene are 11.69 years and 11.56 years, respectively, while their lifetime is 25 years.
\end{abstract}

Keywords: Simple payback time, solar vehicles (SV), electric vehicles (EV), monocrystalline silicon solar panels

\section{Introduction}

Scarcity and cost of fossil fuels combined with their greenhouse gas emissions make the development of non-fossil fuel based methods of transportation a high-priority task. Therefore, academic studies regarding renewable and clean energy like solar energy are rapidly increasing in the last decade. This regenerative, clean and free energy could be harnessed in several ways. This energy can be converted to electric power by using solar photovoltaic (PV) modules. The produced electricity from solar panels can also be stored in the batteries to operate DC motors of solar powered vehicles $[1,2,3,4,5]$. We believe that solar powered vehicles are smart solution for transportation of people particularly for small and flat location cities that have relatively high solar radiation along the year.

Adiyaman City (Latitude $=37,45^{\circ}$, Longitude $=38,17^{\circ}$ and Altitude $=672 \mathrm{~m}$ ) is located in Southeast of Turkey. It has a university called "Adiyaman University". The university campus is about $5 \mathrm{~km}$ far from the city centre. City population is about 210000 and area of the city is $1700 \mathrm{~km}^{2}$. Most of the city roads have the gradient (slope) less than $10 \%$. In the city the solar radiation is relatively high enough to be efficiently used. The annual total solar energy is about $1600 \mathrm{kWh} / \mathrm{m}^{2}$.year.

\section{Materials and Methods}

Firat Force has 6 solar PV modules $\left(2.19 \mathrm{~m}^{2}\right.$ and $\left.330 \mathrm{~W} @ 100 \mathrm{~W} / \mathrm{m}^{2}, 25{ }^{\circ} \mathrm{C}\right)$, a maintenance free long life gel battery pack (8 batteries @ 6V, 190Ah), a regenerative brushless DC electric motor and Commagene has 12 solar PV modules $\left(4.38 \mathrm{~m}^{2}\right.$ and $\left.720 \mathrm{~W} @ 100 \mathrm{~W} / \mathrm{m}^{2}, 25{ }^{\circ} \mathrm{C}\right)$, a maintenance free long life gel battery pack (12 batteries @ 6V, 190Ah), a regenerative brushless DC electric motor. In addition, each vehicle has MPPT (Maximum power point tracker), ECU (Electronic control unit), differential and external automatic charge device. Each vehicle was also equipped with a mechanical steering system, a free front and rear mechanical suspension system, the chassis constructed from

\footnotetext{
* Manuscript received March 28th, 2018; revised April 30th, 2019.

Corresponding author. E-mail address: tkoyuncu@ adiyaman.edu.tr

doi: 10.12720/sgce.8.4.436-442
} 
stainless steel pipe covered with special paint, the frame constructed from impact-resist fiber composite material, an instrument panel, a brake and a gas pedal, all standard systems such as signaling, lighting and warning systems.

The electric energy for charging battery pack is supplied by the PV modules. The energy is converted from the solar energy to electric power through the installation of solar photovoltaic modules located on top of the vehicles (Fig. 1) $[6,7,8,9]$. The supplied electric energy is stored in batteries that feed the DC motor.

In order to determine the total needed force and power for any vehicle to overcome all resistances, Equations 1, 2, 3, 4 and some coefficients were used. The power supplied by PV panels, the efficiency of PV panels, the efficiency of total system were also calculated by using Equations 5, 6, 7 and $8[10,11,12$, $13,14,15,16]$. In addition, if this vehicles are charged with home electricity (if used as electric vehicles and charged with city electric line system) the needed electric energy can be calculated with Equation 9. The annual average solar radiation $\left(525.22 \mathrm{~W} / \mathrm{m}^{2}\right)$, daily sunshine hours $(8.11 \mathrm{~h} /$ day $)$, PV module area $\left(\mathrm{A}_{\mathrm{PV}}=2.19 \mathrm{~m}^{2}\right.$ for Firat Force and $4.38 \mathrm{~m}^{2}$ for Commagene), practical efficiency of PV+MPPT combination $\left(\eta_{\mathrm{PM}}=11.5 \%\right)$ and battery pack+charger combination $\left(\eta_{\mathrm{BA}}=80 \% \ldots 90 \% ; \eta_{\mathrm{CHR}}=85 \% \ldots\right.$ $95 \%$; both $=76.5 \%$ ) must be used for this calculation. Symbols used in equations are described in the Nomenclature.

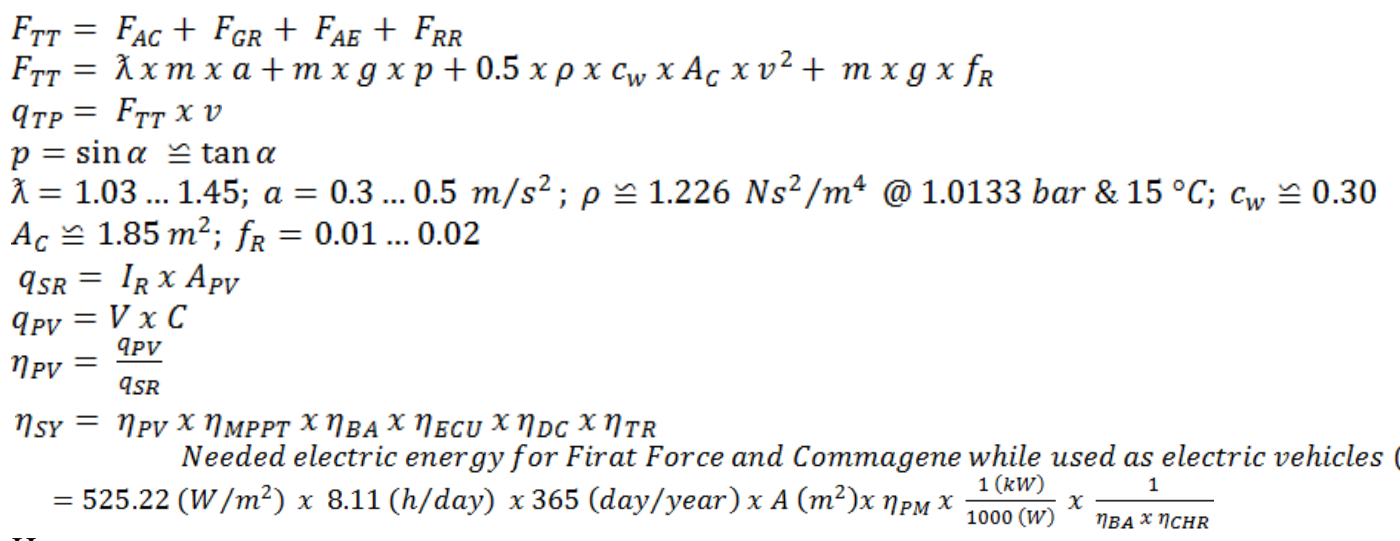

$\chi=1.03 \ldots 1.45 ; a=0.3 \ldots 0.5 \mathrm{~m} / \mathrm{s}^{2} ; \rho \cong 1.226 \mathrm{Ns}^{2} / \mathrm{m}^{4} @ 1.0133$ bar $\& 15^{\circ} \mathrm{C} ; c_{w} \cong 0.30$ Here,

$\eta_{P V} \cong 0.18 ; \eta_{M P P T} \cong 0.95 ; \eta_{B A}=0.80 \ldots 0.90 ; \eta_{E C U}=0.90 \ldots 0.95$

$\eta_{D C} \cong 0.88 ; \eta_{T R} \cong 0.98 ; \eta_{C H R}=0.85 \ldots 0.95$

The test period of the vehicles is one year (June 2010-May 2011) and test transportation distance is approximately $1000 \mathrm{~km}$ (Fig. 2). During the total test period, we have also made some preliminary tests. These preliminary experiments showed us that the best way to see the exact performance or efficiency of any solar vehicles or electric vehicles under city normal traffic conditions is to use the vehicles nonstop with full charged batteries while PV panels off and PV panels on. Therefore, the vehicles were tested while PV panels off (battery pack was charged with electricity only), PV panels on (battery pack was charged with PV panels during use) on the standard road (asphalt-paved road with gradient of about 0\%) and on the mixed road (asphalt-paved and unimproved roads with different gradients of $0 \% \ldots 20 \%$ ) during 3 months (June, July and August 2011) under normal city traffic flow. All tests were made between the times of 10:00 (morning)-17:00 (afternoon). Firat Force was loaded with 2 and 5 persons (driver included) while Commagene loaded with 5 and 10 persons (driver included) during all tests for their total transportation distance. The difference of transportation distance between PV panels off and PV panels on positions was recorded as transportation distance supplied by solar energy. As known, solar energy is renewable and clean energy. On this account, Firat Force and Commagene apparently can be called clean or green vehicles. However in many literatures, all electric vehicles are called green or clean vehicles. It 
should be noted that it completely depends on the energy resources that electric produced from. It is not possible to say that all electric vehicles are green or clean. Besides, the term "efficiency" should be used instead of term "performance" for PV cell, module or panel, in despite of given by some literatures. Because, term "efficiency" is very appropriate to explain the amount of energy conversion from one form to another (form light or solar to electricity for PV cell). However, the term "performance" is particularly suitable to clarify the speed comparision of any activity, process or work.

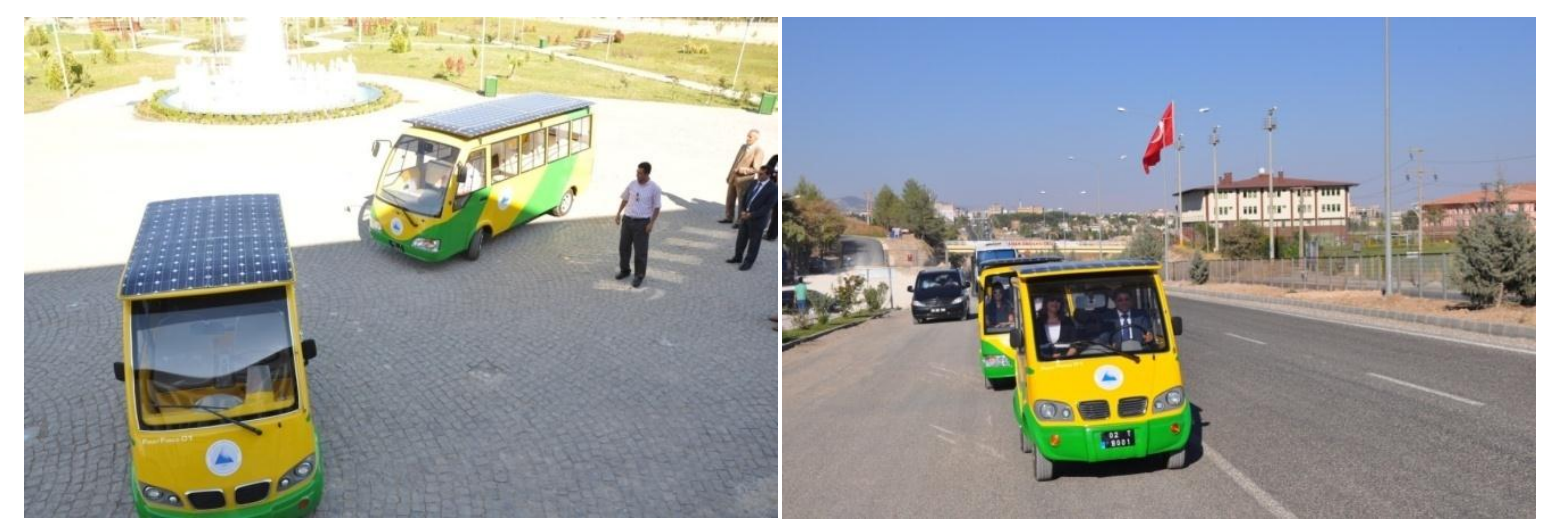

Fig. 1. A view of Firat Force and Commagene PV panel Fig. 2. A view of solar vehicles test activities. location.

In order to calculate the SPT of Firat Force and Commagene when used as SVs and EVs, some assumptions are needed as given below.

\section{Some Assumptions for Firat Force:}

Lifetime of PV modules, MPPT and vehicle components is 25 years.

Lifetime of battery pack is 5 years (battery pack should be renewed or replaced with new 5 times during lifetime of PV modules)

Price of PV modules of Firat Force is $1485 \$(330 \mathrm{~W}$ x 4.5 \$/W)

Price of MPPT of Firat Force is $\mathbf{1 5 0 0} \$$

Price of battery pack of Firat Force during lifetime is $\mathbf{5 0 0 0} \$(1000 \$ \times 5)$

Minimum fuel (gasoline) consumption of equal vehicle with internal combustion engine (Figure 3) of Firat Force is $\mathbf{4} \mathbf{L / 1 0 0 ~} \mathbf{~ k m}$ (for standard road : asphalt-paved road with gradient of about 0\%)

Fuel sale price is $\mathbf{1 . 5 4 7} \$ / \mathrm{L}$ (in Adiyaman, Turkey, January, 2018).

Calculated transportation distances of Firat Force for a year and for lifetime are $11040 \mathrm{~km} / \mathrm{year}$ and $276000 \mathrm{~km} /$ lifetime (for standard road : asphalt-paved road with gradient of about $0 \%$ )

Initial cost (ICS) of PV+MPPT+Battery pack combination (Figure 4) of SV Firat Force $=1485 \$+1500$ $\$+5000 \$=7985 \$$

If Firat Force is used as an $\boldsymbol{E V}$, it is needed to use a charger, battery pack and pay for electric energy (Figure 5). Hence,

Price of battery pack of this electric vehicle during lifetime will be $\mathbf{5 0 0 0} \$$

Price of the charger will be approximately $1000 \$$

Needed electric energy will be $612 \mathrm{kWh} / \mathrm{year}$ and $15300 \mathrm{kWh} /$ lifetime (Equation 9)

Cost of electricity will be $\mathbf{3 7 . 4 3} \$ \mathbf{y e a r}$ and $\mathbf{9 3 5 . 7 5} \$ /$ lifetime (price of electricity is $0.06116 \$ / \mathrm{kWh}$ in January, 2018, Adiyaman, Turkey)

Initial cost (ICS) of Battery pack+Charger+Electricity combination of Firat Force $=5000 \$+1000 \$+$ $936 \$=6936 \$$ 


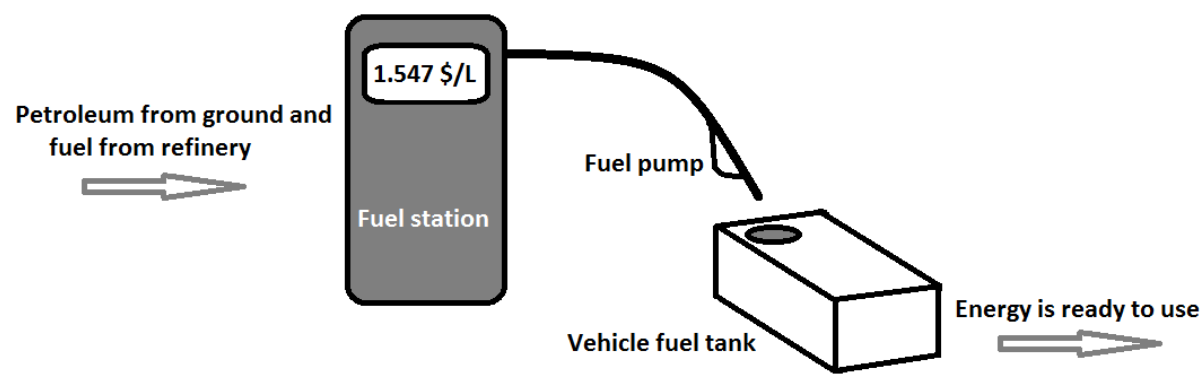

Fig. 3. Combination of fuel system for vehicles that powered with internal combustion engines.

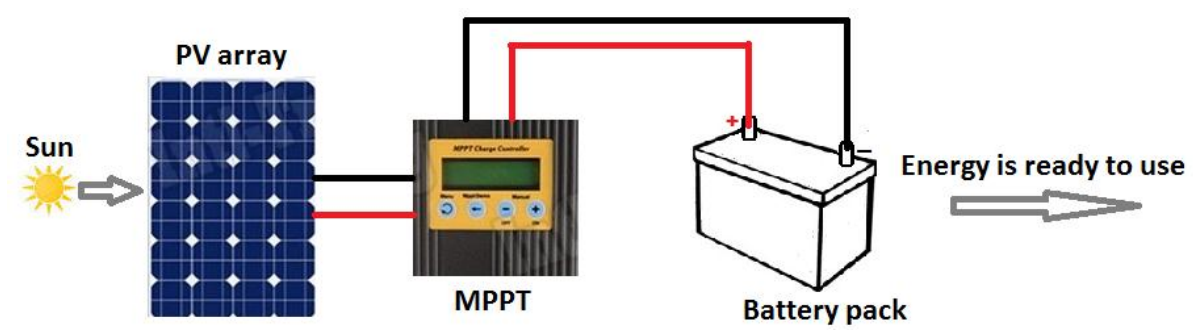

Fig. 4. Combination of PV system for solar powered vehicles.

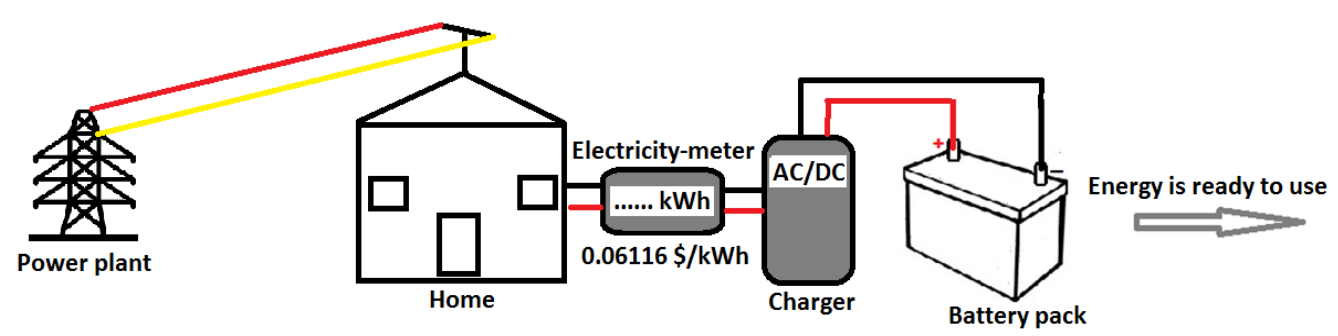

Fig. 5. Combination of electric charging system for electric vehicles.

\section{Some Assumptions for Commagene:}

Lifetime of PV modules, MPPT and vehicle components is 25 years.

Lifetime of battery pack is 5 years (battery pack should be renewed or replaced with new 5 times during lifetime of PV modules)

Price of PV modules of Commagene is $3240 \$(720 \mathrm{~W}$ x $4.5 \$ / \mathrm{W})$

Price of MPPT of Commagene is $2000 \$$

Price of battery pack of Commagene during lifetime is $7500 \$(1500 \$ \times 5)$

Minimum fuel (gasoline) consumption of equal vehicle with internal combustion engine (Figure 3) of Commagene is $\mathbf{5} \mathbf{~} / \mathbf{1 0 0} \mathbf{~ k m}$ (for standard road : asphalt-paved road with gradient of about $0 \%$ )

Fuel sale price is $\mathbf{1 . 5 4 7} \$ / \mathbf{L}$ (in Adiyaman, Turkey, January, 2018)

Calculated transportation distances of Commagene for a year and for lifetime are $14250 \mathrm{~km} / \mathrm{year}$ and $356250 \mathrm{~km} /$ lifetime (for standard road : asphalt-paved road with gradient of about $0 \%$ )

Initial cost (ICS) of PV+MPPT+Battery pack combination of Commagene (Figure 4) $=3240 \$+2000$ $\$+7500 \$=12740 \$$

If Commagene is used as an electric vehicle, it is needed to use a charger, battery pack and pay for electric energy (Figure 5). Hence,

Price of battery pack of this electric vehicle during lifetime will be $7500 \$$

Price of the charger will be approximately $1500 \$$

Needed electric energy will be $1024 \mathrm{kWh} /$ year and $25600 \mathrm{kWh} /$ lifetime 
Cost of electricity will be $\mathbf{6 2 . 6 3} \$ /$ year and $\mathbf{1 5 6 5 . 7 5} \$ /$ lifetime (price of electricity is $0.06116 \$ / \mathrm{kWh}$ in January, 2018, Adiyaman, Turkey)

Initial cost (ICS) of Battery pack+Charger+Electricity combination of Commagene $=7500 \$+1500$ $\$+1566 \$=10566 \$$

Note : All average prices given above has been collected from different websites of companies in January 2018, and losses rates of some devices related to SVs and EVs has also been used for calculation to update the data and to maximize the accuracy $[17,18,19,20,21,22,23]$.

Simple Payback Time (SPT) regarding solar vehicles (SVs) and electric vehicles (EVs) when replaced with gasoline internal combustion engine (ICE) can be calculated as given below [24, 25].

SPT can be calculated for Firat Force with equation of :

$S P T=\frac{\text { Initial cost }(\text { ICS }) \text { of energy supply system }(\$)}{\text { Transp.distance }(\mathrm{km} / \text { year }) x \text { Gasol.fuel cons. } 4(\mathrm{~L}) / 100(\mathrm{~km}) x \text { Gasol. fuel price }(\$ / \mathrm{L})}$

SPT can be calculated for Commagene with equation of :

$S P T=\frac{\text { Initial cost }(I C S) \text { of energy supply system }(\$)}{\text { Transp.distance }(\mathrm{km} / \text { year }) \text { x Gasol.fuel cons. } 5(L) / 100(\mathrm{~km}) \text { xGasol. fuel price }(\$ / L)}$

\section{Results}

Firat Force and Commagene were tested during 3 months (June, July and August 2011) under normal city traffic flow for practical efficiency of PV panels. The average practical PV panel efficiency was seen as approximately $13 \%$ for Firat Force and Commagene. The efficiency of PV panel and MPPT combination and total system efficiency (from PV panel to vehicle wheel) was also seen as approximately $11.5 \%$ and $9 \%$, respectively for both SVs. In addition, the average annual solar radiation and daily sunshine hours were determined as $525.22 \mathrm{~W} / \mathrm{m}^{2}$ and $8.11 \mathrm{~h} /$ day for Adiyaman city, Turkey (Figure 6). The average calculated daily transportation distance depending on months for one year were also given for Firat Force and Commagene (Figure 7 and 8) [9, 26, 27].

The SPT of SVs and EVs when replaced with gasoline ICE was determined as given below :

Simple Payback Time (SPT) of Solar Vehicle (SV) Firat Force when replaced with ICE :

$S P T=\frac{\text { ICS of solar energy supplied system }(\$)}{11040(\mathrm{~km} / \text { year }) x 4(\mathrm{~L}) / 100(\mathrm{~km}) \times 1.547(\$ / \mathrm{L})}=\frac{7985 \$}{683(\$ / \text { year })}=11.69 \mathrm{Year}$

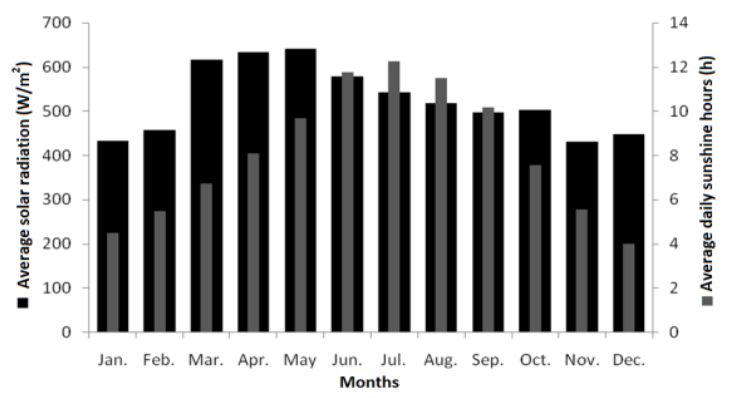

Fig. 6. Average solar radiation (right axis:W/m2) and average daily sunshine duration (left axis:h) related to month.

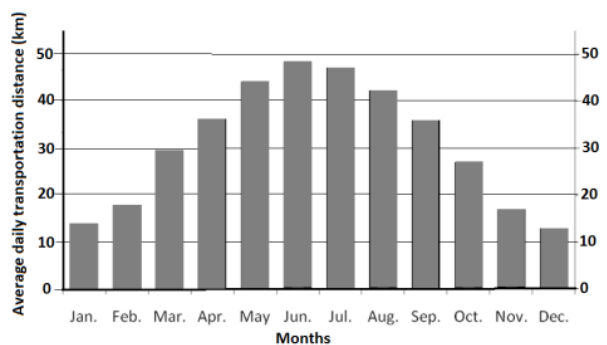

Fig. 7. The average calculated daily transportation distance depending on months for Firat Force.

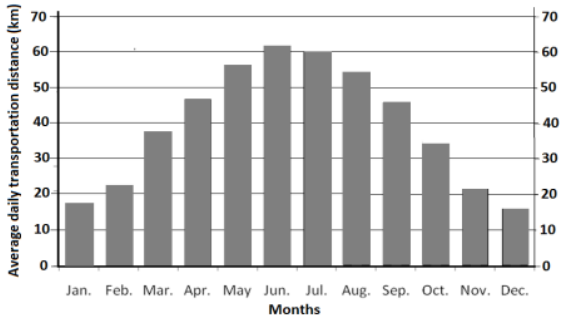

Fig. 8. The average calculated daily transportation distance depending on months for Commagene. 
Simple Payback Time (SPT) of Electric Vehicle (EV) Firat Force when replaced with ICE : $S P T=\frac{I C S \text { of electric energy supplied system }(\$)}{11040(\mathrm{~km} / \text { year }) \times 4(\mathrm{~L}) / 100(\mathrm{~km}) \times 1.547(\$ / \mathrm{L})}=\frac{6936 \$}{683(\$ / \text { year })}=\mathbf{1 0 . 1 5} \mathrm{Year}$

Simple Payback Time (SPT) of Solar Vehicle (SV) Commagene when replaced with ICE : $S P P=\frac{I C S \text { of solar energy supplied system }(\$)}{14250(\mathrm{~km} / \text { year }) \times 5(\mathrm{~L}) / 100(\mathrm{~km}) \times 1.547(\$ / \mathrm{L})}=\frac{12740 \$}{1102(\$ / \text { year })}=11.56 \mathrm{Year}$

Simple Payback Time (SPT) of Electric Vehicle (EV) Commagene when replaced with ICE : SPT $=\frac{\text { ICS of electric energy supplied system }(\$)}{14250(\mathrm{~km} / \text { year }) \times 5(\mathrm{~L}) / 100(\mathrm{~km}) \times 1.547(\$ / \mathrm{L})}=\frac{10566 \$}{1102(\$ / \text { year })}=\mathbf{9 . 5 9} \mathrm{Year}$

As seen from the results that the SPTs are about same for both vehicles and for both energy supply systems when replaced with equal gasoline ICE. When considered the lifetime ( 25 years) of the vehicles, it is clear that the SPTs are lower than the half period of lifetime of both vehicles. In addition, the SPTs of EVs are a little bit lower than SVs. This difference is not important and there is negligible difference between these two energy supply system. It is estimated that this insignificant difference coming from the high price and low efficiency of solar PV energy supply system.

\section{Conclusion}

The main conclusion of this work is that the electricity can be produced from different energy resources such as fosil fuels, hydro, nuclear, geothermal and renewable. Most of these resources are not green or clear and imported by many countries in the world. Therefore, it can be recommended that solar vehicles (SVs) should be preffered instead of electric vehicle (EVs) particullary for small cities as Adiyaman city, Turkey, in despite of a little bit lower simple payback time (SPT) of EVs.

\section{Acknowledgement}

I would like to thank too much to Adiyaman University for supporting this experimental investigation.

\section{Nomenclature}

$a:$ Acceleration, $\mathrm{m} / \mathrm{s}^{2}$

$A_{C}:$ Frontal area of the vehicle, $m^{2}$

$A_{P V}:$ Photovoltaic PV area, $m^{2}$

$C$ : Average current, $A$

$c_{w}:$ Coefficient of drag

$F_{A C}:$ Needed force for acceleration, $N$

$F_{A E}:$ Needed force for aerodynamic resistances, $N$

$F_{G R}:$ Needed force for grade resistance, $N$

$f_{R}$ : Coefficient of rolling friction

$F_{R R}:$ Needed force for rolling resistance, $N$

$q_{S R}$ : Incident solar power, $W$

$q_{T P}:$ Needed total power of the vehicle, $W$

$v$ : Speed of the vehicle, $\mathrm{m} / \mathrm{s}$

$V$ : Average voltage, $V$

\section{Greek}

$\alpha:$ Road grade

$\eta_{B A}:$ Battery efficiency?

$\eta_{D C}:$ DC motor efficiency?

$\eta_{E C U}:$ Electronic control unit (ECU) efficiency?

$\eta_{M P P T}:$ Maximum power point tracker (MPPT) efficiency?

$F_{T T}$ : Needed total force to overcome all resistances, $N \eta_{P V}$ : Photovoltaic (PV) efficiency?

$g:$ Gravitational acceleration, $\mathrm{m} / \mathrm{s}^{2}$

$\eta_{S Y}:$ System efficiency:

$I_{R}:$ Incident solar radiation, $\mathrm{W} / \mathrm{m}^{2}$

$m$ : Vehicle mass, $\mathrm{kg}$

$q_{P V}:$ Photovoltaic $(P V)$ power, $W$

$\eta_{T R}:$ Transmission efficiency:

$\lambda$ :Rotational inertia factor

$\rho:$ Air density, $\mathrm{kg} / \mathrm{m}^{3}$ 


\section{References}

[1] Dayem, AMA. Set-up and performance investigation of an innovative solar vehicle. In: Proc. of 1st International Workshop on Diffusion of New Energy Technologies in Chine, March 25-27, Shanghai, China, 2011.

[2] Garrison, M. The 2007 solar D house. In: Proc. of 5th International Conference on Urban Regeneration and Sustainability, Skiathos Isl., Greece, September 24-26 2008.

[3] Hazami M., Kooli S, Lazaar M, Farhat A, Belghith A. Performance of a solar storage collector. Desalination, 2005; (183): 167-172.

[4] Tsai CS. and Ting CH. Evaluation of a multi-power system for an electric vehicle. International Conference on Control, Automation and Systems (ICCAS 2010), 2010; 1308-1311, Gyeonggi do, South Korea, October 27-30.

[5] Ustun O, Yilmaz M, Gokce C. et al. IEEE International Electric Machines and Drives Conference (IEMDC 2009), Miami, FL., USA. 2009 May 03-06.

[6] Ageev MD, Blidberg DR, Jalbert J. et al. Results of the evaluation and testing of the solar powered AUV and its subsystems. IEEE Workshop on Autonomous Underwater Vehicles, San Antonio, TX. 2002 June 20-21.

[7] Egiziano L, Giustiniani A, Lisi G. et al., Experimental characterization of the photovoltaic generator for a hybrid solar vehicle. IEEE International Symposium on Industrial Electronics. Vigo, Spain, 2007 June 04-07.

[8] Lu W, Yamayee ZA, Melton A. et al., A solar powered battery charger for a hybrid electric vehicle. In: Proc. of 37th Annual Frontiers in Education Conference, Milwaukee, WI. , 2007 October 10-13.

[9] Redpath DAG, Mcllveen-Wright D, Kattakayam T, Hewitt NJ., Karlowski J. Battery powered electric vehicles charged via solar photovoltaic arrays developed for light agricultural duties in remote hilly areas in the Southern Mediterranean region. Journal of Cleaner Production, 2011; (19): 2034-2048.

[10] Koyuncu T, Engin KE and Lule F. Design, manufacture and test of a solar powered minibus (Commagene) for transportation of people in Adiyaman city, Turkey. In: Proc. of $29^{\text {th }}$ European Photovoltaic Solar Energy Conference and Exibition (EU PVSEC 2014), Amsterdam, The Netherlands, 2014 September 22-26.

[11] Koyuncu, T. 2015. Design, manufacture and test of a solar powered car (Firat Force) for transportation of governmental officers in Adiyaman city, Turkey. In: Proc. of The $6^{\text {th }}$ International Congress of Energy and Environment Engineering and Management (CIIEM15), Paris, France, July 22-24.

[12] Cengel YA. and Boles MA. Thermodynamics: an engineering approach (Second edition). McGraw-Hill, Inc., New York, 1994.

[13] Gibson TL, and Kelly NA. Solar photovoltaic charging of Lithium-ion batteries. Journal of Power Sources, 2010; (195): 39283932.

[14] Goktan AG, Guney A. and Ereke M. Tasit frenleri (vehicle brakes: in Turkish). ITU Machine Faculty, Automotive Main Science, Istanbul, 1995.

[15] Holman JP. Experimental methods for engineers (Sixth edition). McGraw-Hill Inc., New York, 1994.

[16] Poulek V. and Libra M. Solar energy: photovoltaics-promossing trend for today and close future. Czech University of Agriculture in Prague, Prague, Czech Republic, 2006.

[17] Apostolaki-losifidou W, Codani P. and Kempton W. Measurement of power loss during electric vehicle charging and discharging. Energy, 2017 ; (127): 730-742.

[18] Forward E, Glitman K, and Roberts D. An assessment of level 1 and level 2 electric vehicle charging efficiency. Vermont Energy investment Corporation Transportation Efficiency Group, March 20, 2013 (revised), project report, URL : https://www.v eic.org/docs/ Transportation /20130320-EVT-NRA-Final-Report.pdf. (accessed : 29.01.2018)

[19] Mousavi SM and Flynn D. Controlled charging of electric vehicles to minimize energy losses in distribution systems. IFAC papers online, 2016; (49-27): 324-329.

[20] Jiang X, Wang J, Han Y and Zhao Q. Coordination dispatch of electric vehicles charging/discharging and renewable energy resources power in micrgrid. Procedia Computer Science (ICICT 2017), 2017; (107): 157-163.

[21] Xu XM, Li RZ, Fu JQ. and Jiang HB. Research on the heat flow field synergy of electric vehicle power cabin at different charge and discharge rates. Applied Thermal Engineering, 2017; (117): 397-408.

[22] URL : http://teslaliving. net/2014/07/07/measuring-ev-charging-efficiency/ (accessed : 29.01.2018)

[23] URL : http://www.electronicdesign.com/power/electric-vehicle-charger-hits-new-efficiency-level (accessed : 29.01.2018)

[24] Foster R, Ghassemi M, Cota A, Solar Energy: Renewable Energy and the Environment, 9: 231-246, first ed. CRC, 2010.

[25] Thumann A, Mehta DP. Handbook of Energy Engineering (Chapter 9, pp. 271-276), sixth ed. CRC Press, Taylor \& Francis, Boca Raton, FL, USA), 2008.

[26] Sorrentino M, Rizzo G. and Arsie I. Analysis of a rule-based control strategy for on-board energy management of series hybrid vehicles. Control Engineering Practice, 2011; (19): 1433-1441.

[27] Koyuncu T. Practical efficiency of photovoltaic panel used for solar vehicles. Earth and Environmental Science (ICGET 2017), 2017; (83): 1-8. 